\title{
Electrophysiological and pharmacological properties of GABAergic cells in the dorsal raphe nucleus
}

\author{
Yoshihiro Gocho - Atsushi Sakai - Yuchio Yanagawa • \\ Hidenori Suzuki · Fumihito Saitow
}

Received: 3 December 2012/ Accepted: 15 December 2012/Published online: 30 December 2012

(C) The Author(s) 2012. This article is published with open access at Springerlink.com

\begin{abstract}
The dorsal raphe nucleus (DRN) is the origin of the central serotonin [5-hydroxytryptamine (5-HT)] system and plays an important role in the regulation of many physiological functions such as sleep/arousal, food intake and mood. In order to understand the regulatory mechanisms of 5-HT system, characterization of the types of neurons is necessary. We performed electrophysiological recordings in acute slices of glutamate decarboxylase 67 -green fluorescent protein knock-in mice. We utilized this mouse to identify visually GABAergic cells. Especially, we examined postsynaptic responses mediated by 5-HT receptors between GABAergic and serotonergic cells in the DRN. Various current responses were elicited by $5-\mathrm{HT}$ and $5-\mathrm{HT}_{1 \mathrm{~A}}$ or $5-\mathrm{HT}_{2 \mathrm{~A} / 2 \mathrm{C}}$ receptor agonists in GABAergic cells. These results suggested that multiple 5-HT receptor subtypes overlap on GABAergic cells, and their combination might control 5-HT cells. Understanding the postsynaptic 5-HT feedback mechanisms may help to elucidate the 5-HT neurotransmitter system and develop novel therapeutic approaches.
\end{abstract}

Y. Gocho · A. Sakai · H. Suzuki · F. Saitow $(\bowtie)$

Department of Pharmacology, Nippon Medical School,

Tokyo 113-8602, Japan

e-mail: f-saitow@nms.ac.jp

Y. Gocho

Department of Pediatrics, Nippon Medical School,

Tokyo 113-8602, Japan

Y. Yanagawa

Department of Genetic and Behavioral Neuroscience, Gunma University Graduate School of Medicine and Japan Science and Technology Agency, CREST, Maebashi 371-8511, Japan

H. Suzuki · F. Saitow

Japan Science and Technology Agency, CREST,

Tokyo 102-0075, Japan
Keywords Dorsal raphe - GABAergic · Serotonin · Electrophysiology

\section{Introduction}

The dorsal raphe nucleus (DRN), which is the origin of the central serotonin (5-hydroxytryptamine; 5-HT) system, plays an important role in regulating many physiological functions, such as sleep/arousal, food intake, and mood. The DRN provides serotonergic innervation to several brain regions, including the cerebral cortex, basal forebrain, mesencephalon, hypothalamus, and thalamus, and it receives reciprocal inputs from these broad brain regions. The DRN is composed of heterogeneous neuronal groups that differ in cellular morphology, electrophysiological properties, and the expression of neurotransmitters, such as 5-HT, gamma-aminobutyric acid (GABA), and glutamate [1]. This heterogeneous organization may correspond to a variety of physiological functions that are involved in serotonergic neurotransmission and complicate the understanding of DRN functions. In addition to 5-HT cells, GABAergic cells consist of another major DRN cell group [1-3]. GABAergic cells function as interneurons in local circuits with serotonergic projection neurons and regulate their output [4]. Therefore, characterization of the properties of each cell type, especially of GABAergic cells, and their interactions may help to elucidate the various functions of the DRN.

To date, many investigations have described the properties of DRN 5-HT cells through in vivo or in vitro electrophysiological recordings with neurochemical identification [5-8]. However, these studies did not directly characterize the properties of DRN GABAergic cells but described GABAergic cells as putative non-5-HT cells that 
do not exhibit tryptophan hydroxylase (TPH) immunoreactivity. Since identifying GABAergic cells under electrophysiological recordings is difficult, the properties of DRN GABAergic cells have been poorly characterized.

In order to characterize GABAergic cells, we used a knockin mouse line in which the expression of green fluorescent protein (GFP) was controlled by the glutamate decarboxylase (GAD) 67 endogenous promoter in order to specifically visualize GABAergic cells [9]. This transgenic mouse line $\left(\right.$ GAD $\left.67^{+/ G F P}\right)$ allows for the identification and characterization of GABAergic cells in the brain [10-12]. The electrophysiological and pharmacological properties of directly identified GABAergic cells in the DRN have not yet been characterized. Thus, this study aimed to characterize the differences in electrophysiological and pharmacological properties in GABAergic and non-GABAergic cells in the DRN of GAD67 $7^{+/ G F P}$ mice with whole-cell patch-clamp recording techniques and immunohistochemistry. The properties of GABAergic cells differed from those of non-GABAergic cells in the DRN. Furthermore, the DRN GABAergic cells were heterogeneous in their postsynaptic responses to 5-HT and selective agonists of $5-\mathrm{HT}_{1 \mathrm{~A}}$ and $5-\mathrm{HT}_{2 \mathrm{~A} / 2 \mathrm{C}}$ receptors.

\section{Materials and methods}

\section{Animals}

The generation of GAD67-GFP knock-in mice have been described previously [9], and these mice, used in the present study, were termed GAD67 ${ }^{+/ G F P}$. The mice were maintained with a genetic background of C57BL/6 at our animal facility. In accordance with a protocol approved by the Ethics Review Committee of Nippon Medical School, we made efforts to minimize the number of animals used and their suffering.

\section{Immunohistochemistry}

Male heterozygous GAD67 $7^{+/ G F P}$ mice aged 24 days $(n=2)$ were deeply anaesthetized with pentobarbital and transcardially perfused with freshly prepared $4 \%$ paraformaldehyde in phosphate-buffered saline (PBS). The midbrain was removed, post-fixed at $4{ }^{\circ} \mathrm{C}$ overnight, and cryoprotected in $20 \%$ sucrose in PBS at $4{ }^{\circ} \mathrm{C}$ overnight. The midbrain was cut into serial transverse cryosections with a cryostat (Leica, Tokyo, Japan). Immunohistochemistry was performed on free-floating sections, as previously described [13]. Briefly, transverse cryosections $(20 \mu \mathrm{m})$ of the midbrain were incubated with a rabbit anti-GFP polyclonal antibody (1:2,000; EMD Millipore, MA, USA) and a sheep anti-TPH polyclonal antibody (1:2,000; Life Technologies, NY, USA) for 3 days at $4{ }^{\circ} \mathrm{C}$. The sections were then incubated with secondary antibodies labeled with
Alexa Fluor 594 (1:2,000; Life Technologies) for GFP and Alexa Fluor 488 (1:2,000; Life Technologies) for TPH. After electrophysiological recording, slices were immersion-fixed overnight in $4 \%$ paraformaldehyde prepared in 0.1 M PBS and then stored in PBS. Fixed sections were incubated with a sheep anti-TPH polyclonal antibody (1:1,000; Life Technologies) for 3 days at $4{ }^{\circ} \mathrm{C}$. Subsequently, these sections were incubated with an Alexa Fluor 488 (1:1,000)-conjugated donkey anti-sheep secondary antibody and streptavidin-conjugated Alexa Fluor 594 $(1: 1,000)$ to visualize the immunohistochemical labeling and biocytin. Images were captured with a high-resolution digital camera (Olympus, Tokyo, Japan).

\section{Electrophysiological recording}

Slices for experiments were prepared from 21- to 27-dayold male GAD67 $7^{+/ G F P}$ mice. The mice were deeply anesthetized by halothane inhalation. Following decapitation, the brains were rapidly removed and placed in ice-cold $\mathrm{Na}^{+}$-deficient saline $\left(\sim 4{ }^{\circ} \mathrm{C}\right)$ that contained $252 \mathrm{mM}$ sucrose, $21 \mathrm{mM} \mathrm{NaHCO} 3,3.35 \mathrm{mM} \mathrm{KCl}, 0.5 \mathrm{mM} \mathrm{CaCl}_{2}$, $6.0 \mathrm{mM} \mathrm{MgCl} 2,0.6 \mathrm{mM} \mathrm{NaH} \mathrm{PO}_{4}$, and $10 \mathrm{mM}$ glucose. Coronal slices $(250 \mu \mathrm{M})$ were cut with a vibratome (Leica) through the entire rostrocaudal extent of the DRN between -4.84 and -4.48 Bregma (according to the atlas of Paxinos and Franklin [26]) and placed in a submerged chamber for at least $1 \mathrm{~h}$ in artificial cerebrospinal fluid (ACSF) that contained $138.6 \mathrm{mM} \mathrm{NaCl}, 3.35 \mathrm{mM} \mathrm{KCl}, 2 \mathrm{mM} \mathrm{CaCl}$, $1.3 \mathrm{mM} \quad \mathrm{MgCl}_{2}, 21.0 \mathrm{mM} \quad \mathrm{NaHCO}_{3}, \quad 0.6 \mathrm{mM} \mathrm{NaH}_{2-}$ $\mathrm{PO}_{4} \cdot 2 \mathrm{H}_{2} \mathrm{O}$, and $10.0 \mathrm{mM}$ glucose. ACSF was maintained at $\mathrm{pH} 7.4$ by bubbling $95 \% \mathrm{O}_{2} / 5 \% \mathrm{CO}_{2}$ gas.

Individual slices were transferred to a recording chamber attached to a microscope stage, continuously perfused with oxygenated ACSF at a flow rate of $1.5 \mathrm{~mL} / \mathrm{min}$, and maintained at room temperature $\left(\sim 27{ }^{\circ} \mathrm{C}\right)$. Borosilicate glass-patch electrodes (World Precision Instruments, FL, USA) with a resistance of 6-12 $\mathrm{M} \Omega$ when filled with an internal solution of $150 \mathrm{mM}$ potassium methanesulfonate, $1.0 \mathrm{mM} \mathrm{KCl}, 0.2 \mathrm{mM}$ K-EGTA, $20 \mathrm{mM}$ HEPES, $3.0 \mathrm{mM}$ $\mathrm{MgATP}_{2}$, and $0.4 \mathrm{mM}$ Na-GTP ( $\mathrm{pH} 7.38$ ) were used for whole-cell recordings of DRN cells. Cells that were visualized under a blue light were considered GFP-positive $(\mathrm{GFP}(+))$, and these were designated GABAergic cells. Cells without GFP were considered GFP-negative (GFP $(-))$, and these were designated non-GABAergic cells. Whole-cell patch-clamp recordings were acquired and controlled with Axon 700B Multiclamp amplifier and pClamp acquisition software (Molecular Devices, CA, USA). In the pharmacological experiments, the amplitudes of membrane current induced by serotonergic agonists were measured from the baseline before application of agonist to peak current amplitude of their responses. 


\section{Chemicals}

The following chemicals were used in this study: 5-HT, $(R)-(+)-8$-hydroxy-2-(di- $n$-propylamino)tetralin hydrobromide (8-OH-DPAT), and (+/-)-2,5-dimethoxy-4-iodoamphetamine hydrochloride (DOI) (Sigma-Aldrich, MO, USA).

Analysis and statistics

The data are presented as the mean \pm standard error of the mean, and $\mathrm{n}$ represents the number of independent experiments. Statistical differences were evaluated with the Tukey-Kramer test. $P$ values $<0.05$ were considered statistically significant.

\section{Results}

Distribution of GFP-positive cells and GFP-negative cells in the DRN of GAD67 $7^{+/ \mathrm{GFP}}$ mice

The DRN of GAD6 $7^{+/ G F P}$ mice contained a large population of brightly fluorescent GFP $(+)$ cell structures, including the soma, dendrites, and axons (Fig. 1a1, b1). In GAD67+/GFP mice, numerous $\operatorname{GFP}(+)$ cells were localized to the lateral DRN, whereas TPH-immunopositive cells were densely present within the midline DRN where GFP $(+)$ cells were hardly observed. Numerous small $(5-10 \mu \mathrm{m}) \mathrm{GFP}(-)$ cells that were TPH-immunonegative were intermingled with GFP $(+)$ cells in the lateral DRN (Fig. 1a, b). This complementary distribution of GFP(+) cells and TPH-immunopositive cells was consistent with a previous study [3]. We obtained whole-cell patch-clamp recordings of the membrane properties of $74 \mathrm{GFP}(+)$ cells and $73 \mathrm{GFP}(-)$ cells in the DRN of GAD67 ${ }^{+/ \mathrm{GFP}}$ mice. All tested GFP( $(+)$ cells were located in the lateral DRN. GFP $(-)$ cells that were located in the midline DRN (mGFP(-)) accounted for twothirds of the tested GFP( - ) cells (37/55), and the remaining tested GFP $(-)$ cells $(18 / 55)$ were located in the lateral DRN $(\operatorname{lGFP}(-))$ (Fig. 1c). After the recordings, $71 \mathrm{GFP}(+), 45$ mGFP $(-)$, and 15 lGFP $(-)$ biocytin-filled DRN cells were reconstituted and immunolabeled with TPH in order to determine whether the cell was a 5-HT cell (Fig. 2a). The majority of stained GFP $(+)$ cells $(77 \%, 55 / 71)$ were TPHimmunonegative, whereas most stained $\operatorname{mGFP}(-)$ cells (91\%, 41/45) were TPH-immunopositive (5-HT cells). All stained lGFP $(-)$ cells were TPH-immunonegative (putative glutamatergic cells, $n=15$ ). However, $23 \%$ of the GFP( $(+)$ cells $(16 / 71)$ had weak TPH-immunoreactivity. These results were consistent with recent study that demonstrated the presence of GAD67-containing 5-HT neurons in the rat DRN [14], but this cell group is remained to be clarified. mGFP $(-)$ cells had significantly larger cell bodies than those of $\mathrm{GFP}(+)$ cells and $\operatorname{lGFP}(-)$ cells. (soma crosssectional area: $\operatorname{mGFP}(-), 162.0 \pm 7.9 \mu \mathrm{m}^{2}$; $\operatorname{GFP}(+)$, $87.9 \pm 3.9 \mu \mathrm{m}^{2} ; 1 \mathrm{GFP}(-), 63.4 \pm 5.0 \mu \mathrm{m}^{2} ; \mathrm{mGFP}(-)$ vs. $\operatorname{GFP}(+), p<0.001 ; \operatorname{mGFP}(-)$ vs. $\operatorname{lGFP}(-), p<0.001$; $\operatorname{GFP}(+)$ vs. $\operatorname{lGFP}(-), \mathrm{p}>0.05)$.

Intrinsic membrane properties of DRN GFP(+) and $\operatorname{GFP}(-)$ cells

We analyzed the intrinsic membrane properties of 74 $\mathrm{GFP}(+), 55 \mathrm{mGFP}(-)$, and $18 \operatorname{lGFP}(-)$ cells in the DRN. Representative examples of action potential (AP) shapes of $\operatorname{GFP}(+), \operatorname{mGFP}(-)$, and $\operatorname{lGFP}(-)$ cells are shown in
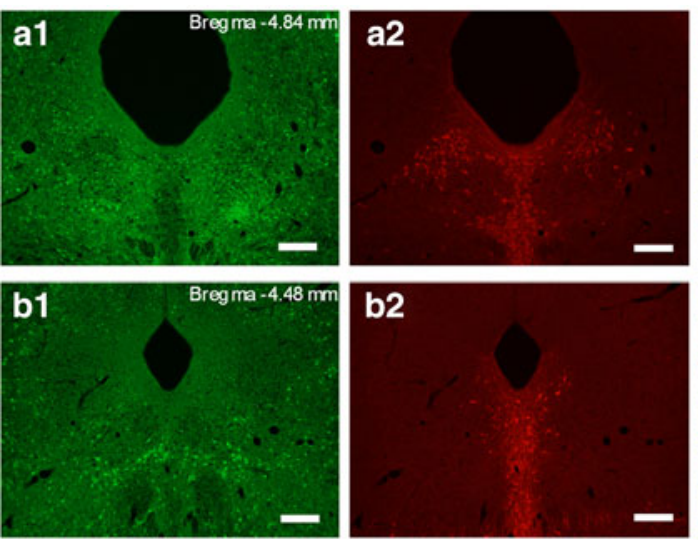

Fig. 1 Distribution of GFP-positive neurons and TPH-containing neurons in the DRN. a, b Fluorescent images of GFP-positive neurons (green) and TPH-containing neurons (red) at the level of the caudal and rostral DRN. The numbers in the upper right of the images represent the distances from Bregma. GFP-positive neurons were present within lateral areas of the DRN and absent at the midline areas, whereas TPH-containing neurons were densely distributed at
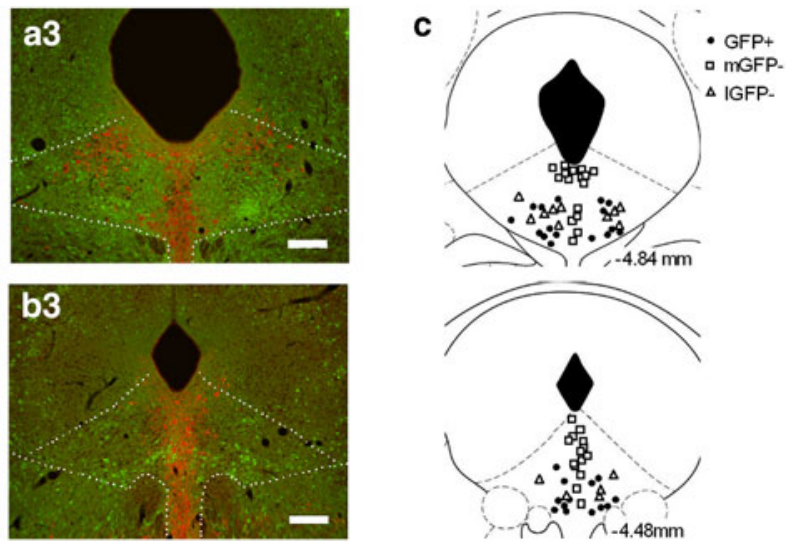

the midline areas. $\mathbf{c}$ Schematic of the sites of the neurons from which electrophysiological properties were obtained. The different symbols represent the types of tested neurons: GFP-positive neurons $(\mathrm{GFP}(+)$; filled circle), GFP-negative neurons located in medial DRN (mGFP $(-)$; square), and GFP-negative neurons located in lateral DRN $(\operatorname{lGFP}(-)$; triangle). The numbers on the lower right of the coronal sections represent the distances from Bregma 

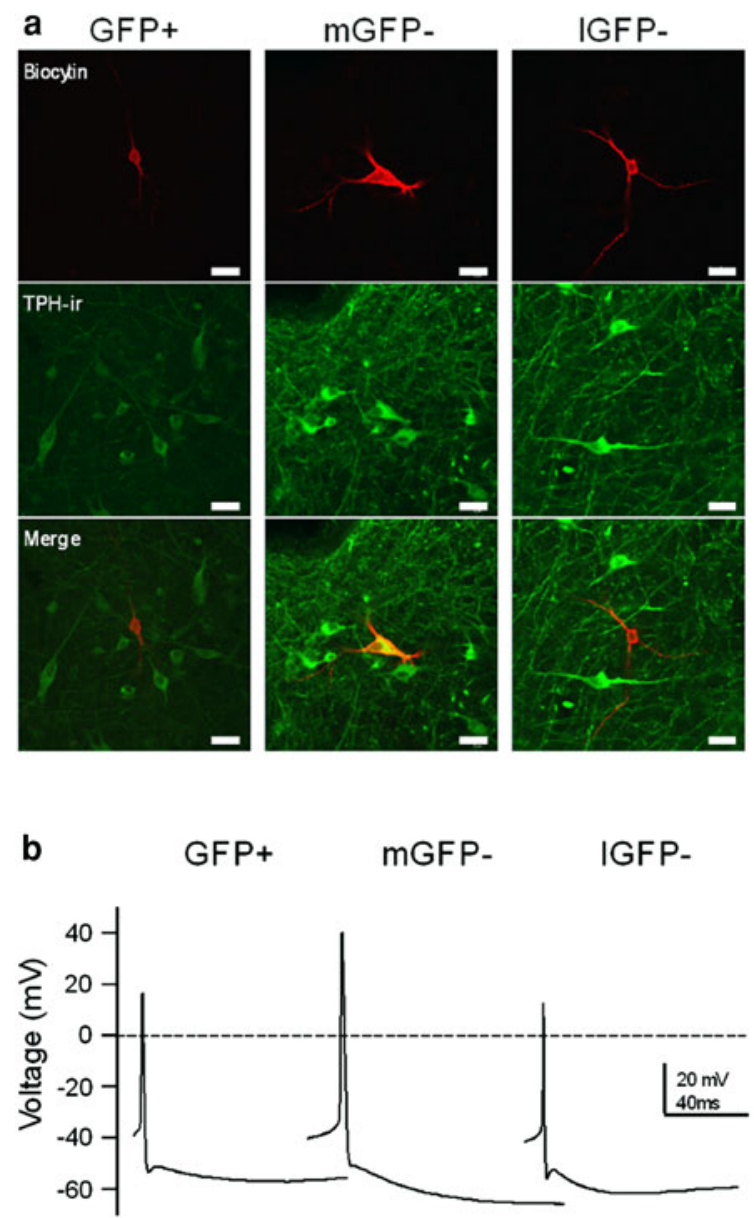

Fig. 2 Morphological and electrophysiological differences among green fluorescent protein (GFP)-positive cells $(\mathrm{GFP}(+))$, GFP-negative cells located in medial DRN ( $\operatorname{mGFP}(-))$, and GFP-negative cells located in lateral DRN $(\operatorname{lGFP}(-))$. a Immunohistochemistry of the 3 types of DRN cells. The cell is double-labeled for both tryptophan hydroxylase (TPH; green) and biocytin (red). Scale bar $10 \mu \mathrm{m}$ in both panels. b Representative action potential (AP) waveforms of $\operatorname{GFP}(+), \operatorname{mGFP}(-)$, and $\operatorname{lGFP}(-)$ neurons. These APs were elicited by the minimum depolarizing holding current. c AP waveforms of

Fig. 2b. Almost no DRN cells were spontaneously active. There were many significant differences in the multivariate analyses between them. The resting membrane potentials of GFP(+) and $1 \mathrm{GFP}(-)$ cells were more depolarized than those of $\operatorname{mGFP}(-)$ cells (Table 1). The threshold potential for AP generation (AP threshold) of GFP(+) cells was significantly hyperpolarized (Table 1 ). In addition, input resistance was significantly larger in GFP(+) cells than in mGFP(-) and IGFP(-) cells (Table 1). The most distinguishable of these differences were the AP waveforms and amplitudes. As shown in Fig. 2b, mGFP(-) cells had larger AP amplitudes and wider AP waveforms compared to
C
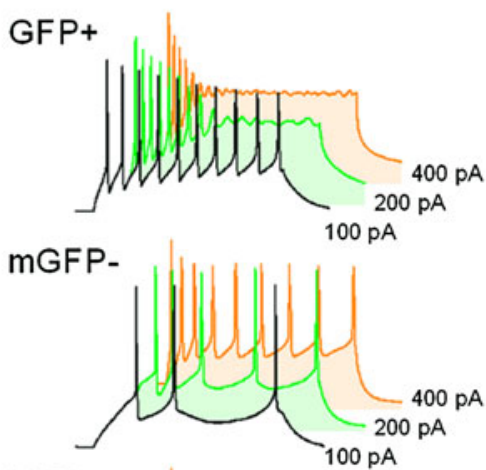

IGFP-

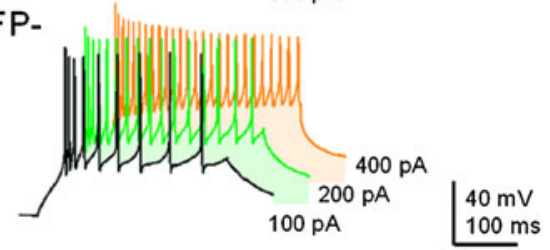

d

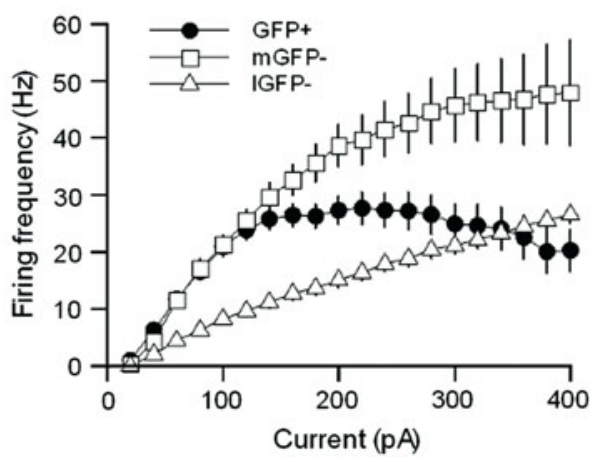

$\operatorname{GFP}(+), \operatorname{mGFP}(-)$, and $\operatorname{lGFP}(-)$ neurons in the DRN that were generated by injecting currents of 100 pA (black), 200 pA (green), and $400 \mathrm{pA}$ (orange), respectively. d Input-output relationship curves of $\operatorname{GFP}(+), \operatorname{mGFP}(-)$, and $\operatorname{lGFP}(-)$ neurons in the DRN $(\operatorname{GFP}(+)$, $n=39 ; \operatorname{mGFP}(-), n=35 ; \operatorname{lGFP}(-), n=18)$. APs were generated by injecting current steps from 0 to $400 \mathrm{pA}$ in increments of $20 \mathrm{pA}$. The firing frequency of AP were calculated at the period of current injection (400 ms)

those of $\mathrm{GFP}(+)$ and $\operatorname{lGFP}(-)$ cells, whereas the AP waveforms of GFP $(+)$ and $\operatorname{lGFP}(-)$ cells were similar. AP overshoot and amplitude of $\operatorname{mGFP}(-)$ cells were significantly larger than those of $\operatorname{GFP}(+)$ and $\operatorname{lGFP}(-)$ cells (Table 1). Regarding AP kinetics, such as half-width, rise time, and decay time, $\operatorname{mGFP}(-)$ cells had significantly broader APs compared to $\operatorname{GFP}(+)$ and $\operatorname{lGFP}(-)$ cells (Table 1). Although most cells had both fast and slow AHPs (fAHP and sAHP) components, some mGFP(-) cells were deficient in the fAHP. The sAHP amplitude of $\operatorname{mGFP}(-)$ cells was significantly larger than those of GFP $(+)$ and lGFP( - ) cells (Table 1). The fAHP amplitude 
Table 1 Electrophysiological properties of GFP(+), medial GFP(-), and lateral GFP(-) cells in the DRN

\begin{tabular}{|c|c|c|c|}
\hline & $\mathrm{GFP}+$ & m GFP- & $1 \mathrm{GFP}-$ \\
\hline Resting membrane potential $(\mathrm{mV})$ & $-69.8 \pm 0.7(74)$ & $-76.6 \pm 0.9 * * *(55)$ & $-69.4 \pm 1.3^{\iint f}(18)$ \\
\hline Input resistance $(\mathrm{M} \Omega)$ & $756 \pm 34^{\dagger}(74)$ & $638 \pm 28 *(55)$ & $588 \pm 54(18)$ \\
\hline AP threshold (mV) & $-38.3 \pm 0.5^{\dagger \dagger}(74)$ & $-34.1 \pm 0.5^{* * *}(55)$ & $-31.8 \pm 1.1(18)$ \\
\hline AP overshoot $(\mathrm{mV})$ & $14.1 \pm 1.0(74)$ & $32.7 \pm 0.7 * * *(55)$ & $14.6 \pm 1.8^{\iint \delta}(18)$ \\
\hline AP amplitude (mV) & $52.4 \pm 1.0^{\dagger \dagger}(74)$ & $66.8 \pm 0.7 * * *(55)$ & $46.4 \pm 1.6^{\iint f}(18)$ \\
\hline fAHP amplitude (mV) & $16.0 \pm 0.7^{\dagger \dagger \dagger}(70)$ & $17.0 \pm 0.7(37)$ & $22.4 \pm 0.9^{\iint f}(18)$ \\
\hline sAHP amplitude (mV) & $21.6 \pm 0.5(69)$ & $29.4 \pm 0.7 * * *(55)$ & $24.2 \pm 1.3^{\iiint}(18)$ \\
\hline Half-width (ms) & $0.70 \pm 0.02(74)$ & $1.35 \pm 0.04 * * *(55)$ & $0.58 \pm 0.04^{\iint f}(18)$ \\
\hline Rise time $10-90 \%(\mathrm{~ms})$ & $0.29 \pm 0.01(74)$ & $0.44 \pm 0.01 * * *(55)$ & $0.25 \pm 0.02^{\iint \rho}(18)$ \\
\hline Decay time $90-10 \%(\mathrm{~ms})$ & $0.42 \pm 0.02(74)$ & $1.00 \pm 0.04 * * *(55)$ & $0.33 \pm 0.03^{\iint \rho}(18)$ \\
\hline
\end{tabular}

Values indicate mean \pm standard error of the mean. The numbers of data are indicated within parentheses. Special symbols $\left(*,{ }^{j},{ }^{\dagger}\right)$ indicate statistically significant differences between groups by the multiple-comparison test, the Tukey-Kramer test $\left(*,{ }^{\dagger},{ }^{\dagger} p<0.05 ; * *, \int{ }^{\dagger},{ }^{\dagger \dagger} p<0.01\right.$;

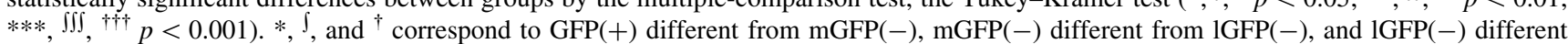
from $\operatorname{GFP}(+)$, respectively

$G F P(+)$ GFP positive, $G F P(-)$ GFP negative, $m G F P(-) \mathrm{GFP}(-)$ cells in the medial DRN, $l G F P(-) \mathrm{GFP}(-)$ cells in the lateral DRN, $A P$ action potential, $f A H P$ fast after hyperpolarization, $s A H P$ slow after hyperpolarization

of $\operatorname{lGFP}(-)$ cells was larger than those of $\mathrm{GFP}(+)$ and mGFP $(-)$ cells (Table 1$)$.

Next, we injected positive current steps from 0 to $400 \mathrm{pA}$ with increments of $20 \mathrm{pA}$ (duration of $400 \mathrm{~ms}$ ) to determine the active membrane properties of the cells (Fig. 2c). As shown in Fig. 2d, the input-output relationship curves of $\mathrm{GFP}(+)$ and $\operatorname{lGFP}(-)$ cells were steeper than that of $\operatorname{mGFP}(-)$ cells. $\operatorname{GFP}(+)$ and $\operatorname{lGFP}(-)$ cells had a similar sensitivity to injected currents $<120 \mathrm{pA}$, but the firing frequency of $\mathrm{GFP}(+)$ cells saturated around $25 \mathrm{~Hz}$ with input currents over $140 \mathrm{pA}$. The firing frequency of APs that were generated by injecting $200 \mathrm{pA}$ for $400 \mathrm{~ms}$ significantly differed among these 3 cell populations $(\mathrm{GFP}(+), 27.3 \pm 2.5 \mathrm{~Hz} ; \operatorname{mGFP}(-), 15.1 \pm$ $1.2 \mathrm{~Hz} ; \operatorname{lGFP}(-), 38.6 \pm 3.7 \mathrm{~Hz} ; \mathrm{GFP}(+)$ vs. $\operatorname{mGFP}(-)$, $p<0.001 ; \operatorname{mGFP}(-)$ vs. $\operatorname{lGFP}(-), p<0.001 ; \mathrm{GFP}(+)$ vs. $\operatorname{lGFP}(-), p<0.01)$.

\section{Effects of 5-HT, 8-OH-DPAT, and DOI}

We next explored the pharmacological effects of 5-HT on the membrane current of DRN GFP $(+)$ and $\operatorname{mGFP}(-)$ cells of GAD67 $7^{+/ \mathrm{GFP}}$ mice. Prior studies have demonstrated that inhibitory effects are induced by $5-\mathrm{HT}$ through the $5-\mathrm{HT}_{1 \mathrm{~A}}$ receptor in DRN 5-HT cells [6-8]. As shown previously, bath applications of 5-HT $(10 \mu \mathrm{M})$ elicited outward currents in all tested $\operatorname{mGFP}(-)$ cells that were considered mostly 5-HT cells $(n=9$, Fig. 3a2). However, in most tested GFP $(+)$ cells, 5-HT elicited an inward current (77.8 \%, $n=21 / 27$; Fig. 3a1). 5-HT-induced outward currents were observed in a minority of $\mathrm{GFP}(+)$ cells $(14.8 \%, n=4 / 27)$, and the remaining $7.4 \%(2 / 27)$ of $\mathrm{GFP}(+)$ cells did not respond to 5-HT. These observations indicated that the 5-HT-mediated pharmacological properties of the membrane currents of DRN GFP $(+)$ cells were heterogeneous.

Furthermore, we explored 5-HT-mediated responses in DRN GFP(+) and $\operatorname{mGFP}(-)$ cells. Because previous studies have demonstrated that the outward and inward currents elicited by 5 -HT were mediated by the activation of $5-\mathrm{HT}_{1 \mathrm{~A}}$ and $5-\mathrm{HT}_{2 \mathrm{~A} / 2 \mathrm{C}}$ receptors in DRN cells, respectively, we used selective agonists, such as 8-OH-DPAT and DOI for the $5-\mathrm{HT}_{1 \mathrm{~A}}$ and $5-\mathrm{HT}_{2 \mathrm{~A} / 2 \mathrm{C}}$ receptor, respectively. Outward currents elicited by 8-OH-DPAT $(5 \mu \mathrm{M})$ were observed in half of the GFP( $(+)$ cells $(9 / 18)$ and $93 \%$ of the mGFP(-) cells (14/15) (Fig. 3b1, b2). mGFP(-) cells had larger outward current amplitudes in response to $8-\mathrm{OH}-$ DPAT than $\operatorname{GFP}(+)$ cells $(\mathrm{GFP}(+), 30.4 \pm 4.0 \mathrm{pA}$ vs. $\operatorname{mGFP}(-), 72.3 \pm 8.3 \mathrm{pA}, p<0.001, t$ test; Fig. $3 \mathrm{~b} 3)$. In $\mathrm{GFP}(+)$ cells, the responses to 8-OH-DPAT varied [inward current, $16.7 \%(n=3 / 18)$; no response, $33.3 \%(n=6 /$ 18)]. These results suggested that DRN GFP $(+)$ cells were heterogeneous for 5-HT receptor expression. We then examined whether the 5-HT-induced inward currents in $\mathrm{GFP}(+)$ cells involved $5 \mathrm{HT}_{2 \mathrm{~A} / 2 \mathrm{C}}$ receptor activation. As shown in Fig. 3c1, the membrane currents were recorded during the sequential application of 5-HT and DOI. Half of the tested GFP $(+)$ cells $(n=7 / 14)$ showed a DOI-induced inward current, while $42.9 \%(n=6 / 14)$ of the GFP( + ( ) cells had no response to DOI (Fig. 3c1). However, the DOI-induced inward current was detected in only a small population of tested $\mathrm{mGFP}(-)$ cells $(18.2 \%, 2 / 11$; Fig. 3c2), and their amplitude was small or negligible (Fig. 3c3). Altogether, these data highlighted the heterogeneity of DRN GFP(+) cells in the regulatory effects through the activation of 5-HT receptors. 
Fig. 3 Effects of 5-HT, 8-OHDPAT, and DOI on membrane currents of GFP-positive and medial GFP-negative cells in the DRN. Representative current traces of GFP $(+)(\mathbf{a} 1$, b1, c1) and $\operatorname{mGFP}(-)(\mathbf{a 2}, \mathbf{b 2}$, c2) cells in the DRN that responded to 5-HT (a), 8-OHDPAT (b), and DOI (c). The lower pie charts display the percentage of responses (inward orange, outward green, and no effect white) to 5-HT (a), 8-OHDPAT (b), and DOI (c) in each type of cell. Scatter plots display the distributions of current amplitudes induced by 5-HT (a3), 8-OH-DPAT (b3), and DOI (c3) in the GFP $(+)$ and $\operatorname{mGFP}(-)$ cells. The current amplitude was sorted by response (inward orange, outward green). Boxes and whiskers indicate mean \pm standard error of the mean and the range from minimum to maximum, respectively a1

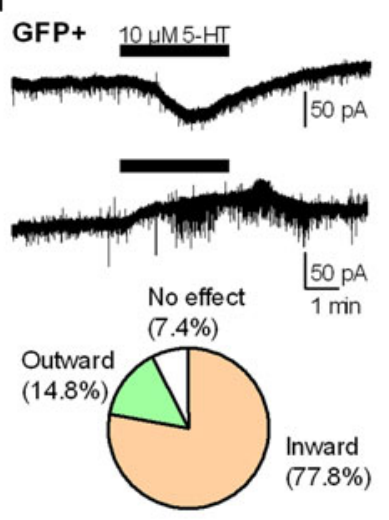

a2

MGFP-

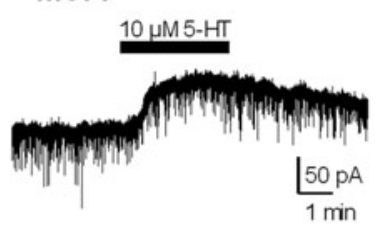

b1

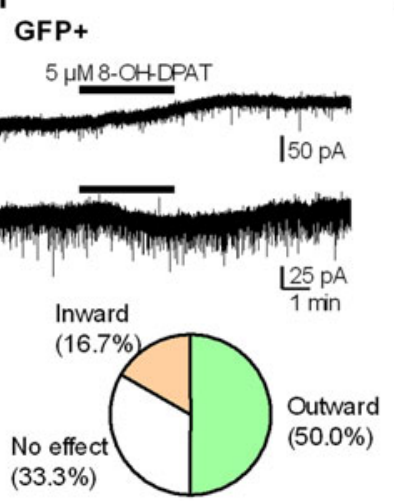

c1

GFP+
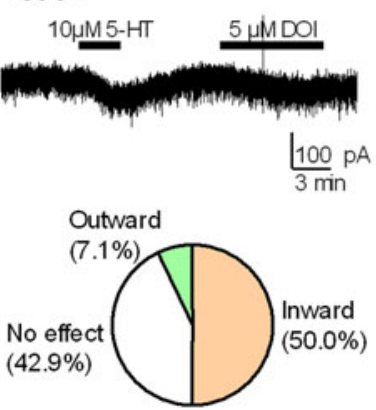

b2

MGFP-

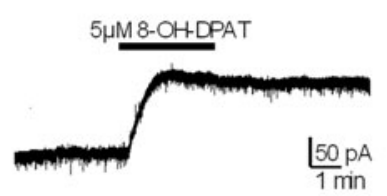

No effect

(6.7\%)

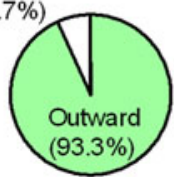

c2

MGFP-

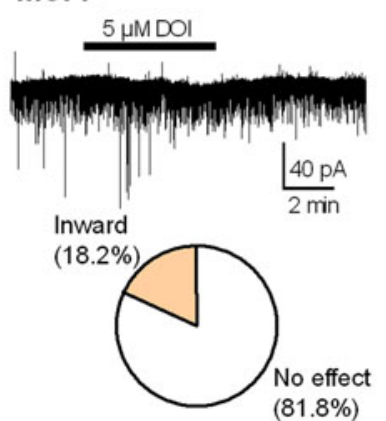

a3

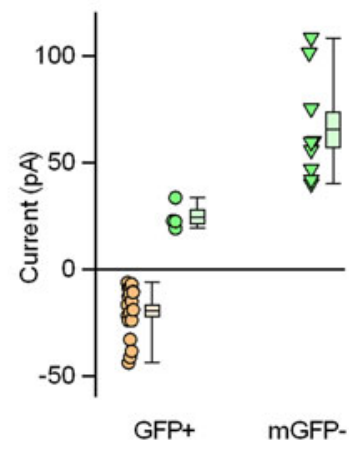

b3

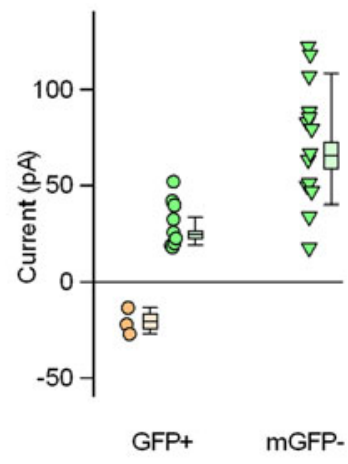

c3

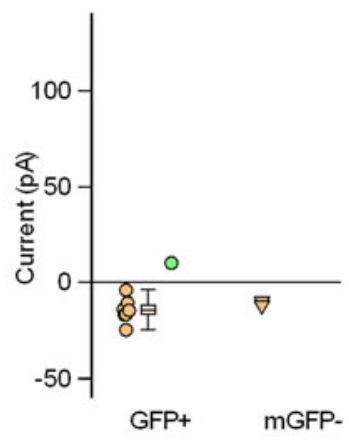

\section{Discussion}

Utility of GAD $67^{+/ \mathrm{GFP}}$ mice

Present study is the first that characterized differences in electrophysiological and pharmacological properties of GABAergic and non-GABAergic cells in the DRN by using GAD67 $7^{+/ G F P}$ mice. To the best of our knowledge, there has been only 1 previous report about the electrophysiological properties of DRN GABAergic neurons [15]. Other studies that have used TPH immunoreactivity for cell typing have reported that the resting membrane potential,
AP threshold, and input resistance did not statistically differ [6, 7]. This was probably because the tested non-5HT neurons potentially contained heterogeneous cells and were not a uniform population. In this study, we demonstrated that GABAergic cells and 5-HT cells within the DRN were localized in distinct subregions (Fig. 1), which was similar to the findings of a previous report [3]. Furthermore, we showed that GFP-negative and TPH-immunonegative small cells were located in the lateral DRN, which was similar to the localization of $\mathrm{GFP}(+)$ cells. These cells were putatively glutamatergic because the neuronal cell types in the DRN, other than 5-HT cells, are 
mainly glutamatergic or GABAergic [2, 3, 16]. However, the properties of DRN glutamatergic cells remain to be elucidated.

Altogether, the identification of cell types with GAD67 $7^{+/ G F P}$ mice enabled a clearer discrimination of the properties of DRN cells.

Intrinsic membrane properties of DRN GABAergic cells

The membrane properties of DRN GABAergic cells had distinctive features: more depolarized resting membrane potential, steeper AP threshold, and higher input resistance. These results suggested that GABAergic cells were easily excitable compared to 5-HT neurons. Moreover, the lower overshoot amplitude and fast AP kinetics may contribute to the high-frequency firing of up to $\sim 25 \mathrm{~Hz}$ in the GABAergic cells. In fact, the input-output relationships induced by positive currents were linear until $100 \mathrm{pA}$ of injection current, and they exhibited frequency adaptation over 100 pA (Fig. 2d).

Physiological and pharmacological implications of DRN GABAergic cells

In the course of pharmacological experiments shown in Fig. 3, we could not exclude synaptic activity-driven indirect actions of serotonergic agonists. However, in most cases, spontaneous postsynaptic currents obtained from recorded cells were not altered by each agonist. Therefore, it is thought that the serotonergic agonist-induced membrane currents reflect direct action of the postsynaptic membrane.

It has been established that feedback inhibition through somatodendritic 5- $\mathrm{HT}_{1 \mathrm{~A}}$ autoreceptors located on DRN 5-HT cells (Fig. 3a2, b2) is an important mechanism for controlling 5-HT neuronal activity [17, 18]. Like 5-HT cells, GABAergic cells play an important role in controlling 5-HT neuronal activity through 5-HT receptor-mediated modulatory actions $[18,19]$. We found that 5-HT elicited excitatory responses in most GABAergic cells, while inhibitory actions were observed in $14.8 \%$ of the GABAergic cells. However, these results cannot be explained simply by the activation of $5-\mathrm{HT}_{1 \mathrm{~A}}$ or $5-\mathrm{HT}_{2 \mathrm{~A} / 2 \mathrm{C}}$ receptors in the subsequent experiments with 8-OH-DPAT or DOI. In the 8-OH-DPAT experiment, outward currents were observed in $50 \%$ of the tested cells, which was a much higher cell population than that in the 5-HT challenge $(14.8 \%)$. However, it was comparable to immunohistochemical and in situ hybridization results that have reported that 40-50 and 10-15\%, respectively, of non5-HT neurons express the $5-\mathrm{HT}_{1 \mathrm{~A}}$ receptor $[15,20]$. Therefore, the discrepancy between the 5-HT and 8-OH-DPAT results can be explained by the effects of other 5-HT receptor subtypes, such as the $5-\mathrm{HT}_{2 \mathrm{~A} / 2 \mathrm{C}}$ receptor, which may overwhelm the response of $5-\mathrm{HT}_{1 \mathrm{~A}}$ receptor activation. Previous studies have shown that the balance between the 5- $\mathrm{HT}_{1 \mathrm{~A}}$ and 5- $\mathrm{HT}_{2 \mathrm{~A} / 2 \mathrm{C}}$ receptors is important in the neuronal regulation by 5 -HT $[8,21]$. Moreover, the inward currents elicited by 8 -OH-DPAT are probably due to the activation of the $5-\mathrm{HT}_{7}$ receptor as $8-\mathrm{OH}-\mathrm{DPAT}$ has a moderate affinity for $5-\mathrm{HT}_{7}$ receptors $[22,23]$.

For the selective $5-\mathrm{HT}_{2 \mathrm{~A} / 2 \mathrm{C}}$ receptor-agonist experiment, DOI elicited inward currents in only $50 \%$ of the tested GABAergic neurons (Fig. 3a3). Hence, only half of the 5-HT-induced inward currents were mediated by $5-\mathrm{HT}_{2 \mathrm{~A} / 2 \mathrm{C}}$ receptor activation in GABAergic cells. The remaining half might be accounted for by the activation of the $5-\mathrm{HT}_{7}$ receptor [18]. That is, in addition to the $5-\mathrm{HT}_{1 \mathrm{~A}}$ and $5-\mathrm{HT}_{2 \mathrm{~A} / 2 \mathrm{C}}$ receptors, $5-\mathrm{HT}_{7}$ receptors might be implicated in the postsynaptic effects of DRN GABAergic neurons. Actually, the 5- $\mathrm{HT}_{7}$ receptor, which is expressed in some GABAergic neurons, contributes to GABA release to regulated 5-HT neurons in the DRN [24, 25].

In heterogeneous DRN neurons, competitive/synergistic actions of multiple 5-HT receptor subtypes induce distinct signaling properties and contribute to a diverse 5-HT neurotransmitter system. These complex regulations have been implicated in the etiology and treatment of many common psychiatric disorders. More extensive explorations of 5-HT receptor subtypes, including their properties, distributions, and interactions, are necessary for the development of novel therapeutic strategies that target 5-HT receptor subtypes.

Acknowledgments We thank Yasunori Mikahara for his technical assistance. This work was supported by CREST of Japan Science and Technology Agent (JST), a Grant-in-Aid for Scientific Research on Priority Areas from MEXT, a Grant-in-Aid for Scientific Research from JSPS and Takeda Science Foundation.

Open Access This article is distributed under the terms of the Creative Commons Attribution License which permits any use, distribution, and reproduction in any medium, provided the original author(s) and the source are credited.

\section{References}

1. Jacobs BL, Azmitia EC (1992) Structure and function of the brain serotonin system. Physiol Rev 72:165-229

2. Fu W, Le Maître E, Fabre V, Bernard JF, David Xu ZQ, Hökfelt $\mathrm{T}$ (2010) Chemical neuroanatomy of the dorsal raphe nucleus and adjacent structures of the mouse brain. J Comp Neurol 518:3464-3494

3. Brown RE, McKenna JT, Winston S, Basheer R, Yanagawa Y, Thakkar MM, McCarley RW (2008) Characterization of GABAergic neurons in rapid-eye-movement sleep controlling regions of the brainstem reticular formation in GAD67-green fluorescent protein knock-in mice. Eur J Neurosci 27:352-363

4. Liu R, Jolas T, Aghajanian G (2000) Serotonin 5- $\mathrm{HT}_{2}$ receptors activate local GABA inhibitory inputs to serotonergic neurons of the dorsal raphe nucleus. Brain Res 873:34-45 
5. Li YQ, Li H, Kaneko T, Mizuno N (2001) Morphological features and electrophysiological properties of serotonergic and nonserotonergic projection neurons in the dorsal raphe nucleus. An intracellular recording and labeling study in rat brain slices. Brain Res 900:110-118

6. Beck SG, Pan YZ, Akanwa AC, Kirby LG (2004) Median and dorsal raphe neurons are not electrophysiologically identical. J Neurophysiol 91:994-1005

7. Kirby LG, Pernar L, Valentino RJ, Beck SG (2003) Distinguishing characteristics of serotonin and non-serotonin-containing cells in the dorsal raphe nucleus: electrophysiological and immunohistochemical studies. Neuroscience 116:669-683

8. Marinelli S, Schnell SA, Hack SP, Christie MJ, Wessendorf MW, Vaughan CW (2004) Serotonergic and nonserotonergic dorsal raphe neurons are pharmacologically and electrophysiologically heterogeneous. J Neurophysiol 92:3532-3537

9. Tamamaki N, Yanagawa Y, Tomioka R, Miyazaki J, Obata K, Kaneko T (2003) Green fluorescent protein expression and colocalization with calretinin, parvalbumin, and somatostatin in the GAD67-GFP knock-in mouse. J Comp Neurol 467:60-79

10. Hirono M, Saitow F, Kudo M, Suzuki H, Yanagawa Y, Yamada M, Nagao S, Konishi S, Obata K (2012) Cerebellar globular cells receive monoaminergic excitation and monosynaptic inhibition from Purkinje cells. PLoS ONE 7:e29663

11. Ono M, Yanagawa Y, Koyano K (2005) GABAergic neurons in inferior colliculus of the GAD67-GFP knock-in mouse: electrophysiological and morphological properties. Neurosci Res $51: 475-492$

12. Bang SJ, Commons KG (2012) Forebrain GABAergic projections from the dorsal raphe nucleus identified using GAD67-GFP knock-in mice. J Comp Neurol 520:4157-4167

13. Muto Y, Sakai A, Sakamoto A, Suzuki H (2012) Activation of $\mathrm{NK}_{1}$ receptors in the locus coeruleus induces analgesia through noradrenergic-mediated descending inhibition in a rat model of neuropathic pain. Br J Pharmacol 166:1047-1057

14. Shikanai H, Yoshida T, Konno K, Yamasaki M, Izumi T, Ohmura Y, Watanabe M, Yoshioka M (2012) Distinct neurochemical and functional properties of GAD67-containing 5-HT neurons in the rat dorsal raphe nucleus. J Neurosci 32:14415-14426

15. Allers KA, Sharp T (2003) Neurochemical and anatomical identification of fast- and slow-firing neurones in the rat dorsal raphe nucleus using juxtacellular labelling methods in vivo. Neuroscience 122:193-204
16. Commons KG (2009) Locally collateralizing glutamate neurons in the dorsal raphe nucleus responsive to substance $\mathrm{P}$ contain vesicular glutamate transporter 3 (VGLUT3). J Chem Neuroanat $38: 273-281$

17. Hajós M, Hajós-Korcsok E, Sharp T (1999) Role of the medial prefrontal cortex in 5- $\mathrm{HT}_{1 \mathrm{~A}}$ receptor-induced inhibition of 5-HT neuronal activity in the rat. Br J Pharmacol 126:1741-1750

18. Sharp T, Boothman L, Raley J, Quérée P (2007) Important messages in the 'post': recent discoveries in 5-HT neurone feedback control. Trends Pharmacol Sci 28:629-636

19. Boothman LJ, Allers KA, Rasmussen K, Sharp T (2003) Evidence that central $5-\mathrm{HT}_{2 \mathrm{~A}}$ and $5-\mathrm{HT}_{2 \mathrm{~B} / \mathrm{C}}$ receptors regulate $5-\mathrm{HT}$ cell firing in the dorsal raphe nucleus of the anaesthetised rat. Br J Pharmacol 139:998-1004

20. Day HE, Greenwood BN, Hammack SE, Watkins LR, Fleshner M, Maier SF, Campeau S (2004) Differential expression of 5HT$1 \mathrm{~A}, \alpha_{1 \mathrm{~b}}$ adrenergic, CRF-R1, and CRF-R2 receptor mRNA in serotonergic, gamma-aminobutyric acidergic, and catecholaminergic cells of the rat dorsal raphe nucleus. J Comp Neurol 474:364-378

21. Craven RM, Grahame-Smith DG, Newberry NR (2001) 5-HT $\mathrm{T}_{1 \mathrm{~A}}$ and $5-\mathrm{HT}_{2}$ receptors differentially regulate the excitability of 5-HT-containing neurones of the guinea pig dorsal raphe nucleus in vitro. Brain Res 899:159-168

22. Wood M, Chaubey M, Atkinson P, Thomas DR (2000) Antagonist activity of meta-chlorophenylpiperazine and partial agonist activity of $8-\mathrm{OH}-\mathrm{DPAT}$ at the $5-\mathrm{HT}_{7}$ receptor. Eur $\mathrm{J}$ Pharmacol 396:1-8

23. Chapin EM, Andrade R (2001) A 5- $\mathrm{HT}_{7}$ receptor-mediated depolarization in the anterodorsal thalamus. I. Pharmacological characterization. J Pharmacol Exp Ther 297:395-402

24. Glass JD, Grossman GH, Farnbauch L, DiNardo L (2003) Midbrain raphe modulation of nonphotic circadian clock resetting and 5-HT release in the mammalian suprachiasmatic nucleus. J Neurosci 23:7451-7460

25. Roberts C, Thomas DR, Bate ST, Kew JN (2004) GABAergic modulation of 5- $\mathrm{HT}_{7}$ receptor-mediated effects on 5-HT efflux in the guinea-pig dorsal raphe nucleus. Neuropharmacology 46:935-941

26. Paxinos G, Franklin KBJ (2001) The mouse brain in stereotaxic coordinates, 2nd edn. Academic, San Diego 